\title{
Biopolitics, Borders, and Refugee Camps: Exercising Sovereign Power Over Nonmembers of the State
}

\author{
Olga Zeveleva \\ National Research University Higher School of Economics
}

Ulitsa Myasnitskaya 22 building 1, room 506, Moscow, Russian Federation, 101000, ozeveleva@hse.ru

Olga Zeveleva is a research associate at the Laboratory for Political Studies at the National Research University Higher School of Economics. She studies the sociology of migration, co-ethnic migration, and mobility. She has written extensively on biographical methods in sociology, on post-Soviet migration, and on co-ethnic migration policy in comparative perspective. Her current research focuses on the discursive construction of migrant identity.

\section{Funding}

The research leading to these results has received funding from the Basic Research Program at the National Research University Higher School of Economics. 


\section{Biopolitics, Borders, and Refugee Camps: Exercising Sovereign Power Over Nonmembers of the State}

This article addresses the relationship between the concepts of national identity and biopolitics by examining a border-transit camp for repatriates, refugees and asylum seekers in Germany. Current studies of detention spaces for migrants have drawn heavily on Agamben's reflection on the "camp" and "homo sacer," where the camp is analyzed as a space in permanent state of exception, in which the government exercises sovereign power over the refugee as the ultimate biopolitical subject. But what groups of people can end up at a camp, and does the government treat all groups in the same way? This article examines the German camp for repatriates, refugees and asylum seekers as a space where the state's borders are demarcated and controlled through practices of bureaucratic and narrative differentiation between various groups of people. The author uses the concept of detention space to draw a theoretical link between national identity and biopolitics, and demonstrates how the sovereign's practices of control and differentiation at the camp construct German national identity through defining "nonmembers" of the state. The study draws on ethnographic fieldwork at the German border transit camp Friedland and on a discourse analysis of texts produced at the camp or for the camp.

Keywords: refugees; refugee camp; biopolitics; spaces of detention; borders.

\section{Introduction}

The German refugee camp Friedland is officially called a "border transit camp" despite its geographic location precisely in the middle of present-day Germany. Established in 1945 by British occupation forces on the border of the British, American and Soviet occupation zones, today the camp hosts about 650 displaced persons from all over the world. They file for asylum or residency and reside at the camp from several weeks to 18 months while waiting for preliminary decisions on their legal status in Germany. They can then be granted asylum, granted residency, or deported. At the camp, the sovereign power of the German state delineates membership, casts nonmembers out of the political community and eventually 
beyond the physical borders of the country, and, in doing so, constitutes the identity of the German state. Thus, the camp reinforces the sovereign state's capacity to decide which forms of life lie beyond its political purview, and to classify them as "nonmembers" through abandoning them. In this paper, I contend that the state exercises sovereign power not only to create a community of members, but also to create a hierarchy of nonmembers who retain ties with the state by virtue of having been abandoned by it.

In making this argument, I am indebted to two lines of research: conceptualizations of the modern detention space as a "state of permanent exception," informed by Giorgio Agamben's work Homo Sacer (1998); and the work on national identity construction in the field of critical geography studies and "spatial turn" sociology. My argument has also been informed by an ethnographic field study conducted at a German space of detention. When the study of national identity is supplemented by a biopolitical framework and informed by this empirical case study, we can show how national identity constructs are produced in specific spaces where the modern nation-state uses its sovereign power to define political life and bare life, its members and its nonmembers. A biopolitical framework allows us to focus on the nonmembers, who retain their relationship to the sovereign through being defined by the sovereign as depoliticized subjects. The paper demonstrates specifically how the German state constructs its national identity by drawing from an ethnographic field study at a German detention space called "border transit camp Friedland." I examine the boundaries set up within this detention space and show how they, in turn, delineate the space of the nationstate.

Thus, this paper builds its argument in two steps: first, I outline a theoretical contribution by bridging the study of national identity and Agamben's biopolitical approach using a spatial approach to the social sciences. Second, I examine the case of a border transit 
camp for refugees, asylum seekers and repatriates, where hierarchies of "campers" connote the discursive contours of the nation-state.

\section{Spatial articulations of national identity}

In this article, I treat national identity not as a collective identity of the public, but rather as an identity purported by the political order, or, to use Agamben's terms, by the "sovereign." This means that I refer not necessarily to shared "symbols and meanings which are publicly circulating" among a "mass of laypeople" (Peters 2002, 12), but rather to symbols, images, and orders produced specifically by government organizations, political parties, and state legislation. In this way, my approach to national identity is situated in the constructivist approach to the nation as a socially constructed entity (following Gellner, Anderson, and Hobsbawm), but is also supplemented by Agamben's conceptualization of sovereign power as the force that delineates inclusion and exclusion in the modern Western nation-state.

Edward Said, Stuart Hall, and Benedict Anderson have argued that space is an important framing device in the creation of cultural imaginaries that make up the modern nation-state. Following a constructivist approach, I contend here that governments of nationstates determine the inclusion of members based on historic, cultural, linguistic, "ethnic," or other elements (Rembold and Carrier 2011, 363). Inclusion can be defined in citizenship laws, migration laws, through political rights of residents, at border control points, as well as in spaces that embody these regulations. In defining such boundaries, sovereign states also determine who is "the other" (Rembold and Carrier 2011, 363). National identity constructions are informed by such patterns of inclusion and exclusion.

National identity has been an object of academic inquiry primarily in area studies as well as in the fields of cultural geography and critical geography. Area studies scholars focus on the construction of certain characteristics as markers of specific national identities, 
grounded in the history, cultural history, or political structure of that state (Peters 2002). Geographers, on the other hand, have made some attempts to conceptualize and theorize national identity at a higher level of abstraction. Most notably for us, geographers have informed the study of national identity from the perspective of spatial structures (Lowenthal et al. 1994; Herb 1999, 31-49). According to geographer Karl Schlögel, the spatial turn gained currency (both in geography and in other social sciences) in response to major historical events like the fall of the Berlin wall in 1989, and again following the September $11^{\text {th }}$ attacks in 2001 (Schlögel 2003, 63), as well as in the wake of the breakup of the Soviet Union (Kaplan and Herb 2011, 250).

The spatial turn in the social sciences more broadly implies "a reworking of the very notion and significance of spatiality to offer a perspective in which... geography is not relegated to an afterthought of social relations, but is intimately involved in their construction" (Warf and Arias 2008). In his seminal work on the sociology of space called The Production of Space, Henri Lefebvre (1991) developed the argument that space is socially produced. He proposed a "trialectic of spatiality:" instead of treating space as an objective backdrop to social relations, Lefebvre conceptualized space as produced by a threeway relationship between cultural practices, representations, and imaginations. For Lefebvre, place is a particular form of space which emerges through acts of naming and imagining.

The spatial turn has also allowed social scientists to conceptualize social phenomena in terms of centers, peripheries, borders and displacements (Kaplan and Herb 2011, 349). Extending this premise to the concepts of nationalism and national identity, geographers David Kaplan and Guntram Herb claim that "nationalism is an intrinsically geographical doctrine in that it seeks to conjoin a self-identified group of people - a 'nation' - within a sovereign, bounded geographical area - a 'state"' $(2011,349)$. 
Elements of this approach have been criticized and dubbed a "territorial trap" that prevents the social sciences from engaging with "non-territorial" dynamics (Agnew 1994; Shah 2012). In response to such criticism, I have chosen to view national identity constructions as contending with their geographical reach, but not enclosed within them: sometimes national identity constructions legitimize borders and boundaries, sometimes they are rendered in cyberspace, and sometimes they are constricted across space by diaspora populations, international organizations, or foreign policy. Against the backdrop of an evolving relationship between national identity and bounded space today (Kaplan and Herb 2011, 350), I propose to examine national identity not just in terms of "inside" and "outside" (Horner and Rule 2013), but rather in terms of the multilayered configurations of a nationstate's "outside." This attention to the "outside" of the state and of identity echoes Agamben's ideas of abandonment by the sovereign. In this article, I examine the camp as a space "outside" the state, which is simultaneously an articulation of state power. Thus, the camp is treated as a project that shapes national identity through processes of classification, hierarchization, and homogenization of a space beyond the nation-state.

\section{Agamben, sovereign power, and exclusion}

The spatial conceptualization of national identity outlined above can benefit from a further theorization of the concept of “outside." This is where Agamben's biopolitical framework proves helpful. By supplementing the spatial approach to national identity with biopolitics, we can examine more closely the "outside" of political life - that which has been excluded by the nation state - in order to understand certain characteristics of that nation-state. I propose here to use Agamben's conceptualization of sovereign power in order to take a look at how this "outside" retains ties with the nation-state, and how it is used to reaffirm national identity. 
Similarly to how Kaplan and Herb (2011) and Horner and Rule (2013) emphasize the nation-state's relation to its sovereign geographical area, Agamben conceptualizes the nationstate as a "defined by the three elements land, order, birth" (Agamben 1998, 99). According to Agamben, the political system of the modern nation-state "was founded on the functional nexus between a determinate localization (land) and a determinate order (the Sate)" and mediated through birth, of either life or the nation $(1998,99)$. For Agamben, the category known as "the people" is the "source of every identity but must, however, continually be redefined and purified through exclusion, language, blood, and land" $(1998,100)$. The concept of exclusion is central here. Agamben describes sovereign power as the force by which inclusion and exclusion are delineated, and the force that blurs inclusion and exclusion together in the modern Western nation-state. An object of sovereign power is excluded and simultaneously included because the sovereign abandons the object, and through this abandonment retains its link with the object. Here, I will use sovereign power to mean power exercised by the nation-state; thus, government organizations and agencies of the nation-state are sources of sovereign power, and their activities are manifestations of it.

It is largely through the figure of the stateless person and the refugee that first Hannah Arendt (1958), and then Agamben (1998) analyze the politics of sovereign power in the West. Much like Arendt calls stateless persons "the most symptomatic group in contemporary politics" (Arendt 1958, 277), Agamben describes the refugee as the exemplary symbolic representation of contemporary social and political reality. Agamben draws heavily on Arendt's work, in which she describes the intrinsic connection between "the sovereign right of states in matters of nationality and expulsion" and human rights, or "Rights of Man" (Arendt 1958, 286). In the chapter "The Decline of the Nation-State and the End of the Rights of Man" of "The Origins of Totalitarianism" (1958), Arendt argues that when human beings can no longer claim protection by their own governments, Rights of Man become 
unenforceable $(1958,293)$. Moreover, Arendt makes the claim that the very structure of the nation-state itself "dissolved" $(1958,290)$ as the number of people outside the jurisdiction of national laws grew, with no other legal framework emerging to protect them $(1958,286)$. According to Arendt, as numbers of refugees and stateless people increased, "an anarchic mass of over-and underprivileged individuals" replaced the principle of equality before the law, which had been the central principle defining nation-states $(1958,290)$. For Arendt, "the inability of nation-states to treat stateless people as legal persons" and the extension of "arbitrary rule by police decree" over stateless people tempts states to eventually "deprive all citizens of legal status and rule them with an omnipotent police” (1958, 290). In Homo Sacer (1998), Agamben focuses on this notion of omnipotent rule over human beings deprived of protection, arguing that the law's abandonment of human beings is in fact tantamount to including the very concept of abandonment within the law. Agamben is interested in what happens to those Arendt describes as people "forced to live outside the common world" (Arendt 1958, 302), at what Agamben calls "the threshold of indistinction," where the exception to the law is the rule.

Central to Agamben's understanding of law and exception is the spatial ordering of political life based on an "us inside - them outside" divide (Bülent Diken and Laustsen 2005). Here, Agamben seems to offer a spatial reading of Carl Schmitt: he takes on Schmitt's use of the ancient Greek word nomos for "law," which implies for Schmitt a "unity of order and orientation," the belonging of space and law together (Schmitt 2003, 42). Schmitt defines the sovereign as whoever can decide on the state of exception. Agamben builds on this definition, and claims that the fundamental paradox of the Western political order is the fact that the sovereign is both inside and outside the normal juridical order, as the sovereign not only creates law and order, can suspend it. Explaining this dichotomy, Agamben the "fundamental biopolitical fracture of the West" to be the separation between polis (political 
life) on the one hand, and zoe (biological life) on the other hand. When the latter is excluded from the former in an act of abandonment by the sovereign, bare life is produced (Hussain and Ptacek 2000). This act of abandonment by the sovereign is fundamental to Agamben's understanding of modern political power as a kind of "inclusive exclusion" (Ek 2006, 366). For Agamben, exclusion always occurs in relation to a sovereign, for it exists only in the form of the sovereign's suspension: "he who has been banned is not, in fact, simply set outside the law and made indifferent to it but rather abandoned by it, that is, exposed and threatened on the threshold in which life and law, outside, and inside, become indistinguishable" (Agamben 1998, 28). In this way, Agamben takes the spatial ideas of an "inside" and an "outside" of political life a step farther: after being banned, all who find themselves on the outside remain intrinsically connected to the sovereign.

\section{The camp}

In Homo Sacer, the camp is a place formed at the disjunction of the nation-state: while outside the camp there are citizens who have a political existence, inside the camp there is only bare life - a mass of people stripped of their political subjectivity. According to Agamben, the camp was born out of a state of exception, or the sovereign's temporary suspension of the normal political order. This state of exception then became permanent, and the camp became a manifestation of all social structures of modernity. Agamben traces the origins of the camp to Spanish Cuba at the end of the $19^{\text {th }}$ century and to English South Africa at the start of the $20^{\text {th }}$ century, thus showing how colonizers engaged in the classification of human beings according to a racist hierarchy. The spatial order of a camp allows for classification and codification of human beings, and thus it is a form of "organization of bare life that the sovereign chooses, a pure and absolute biopolitical space and the hidden paradigm of the political space of modernity" (Ek 2006, 368). At the camp, 
bare life and juridical rule become blurred and enter a threshold of indistinction. To Agamben, the refugee is the ultimate figure representing "the people" of the modern nationstate.

Scholars of displacement and incarceration have been examining empirical cases of migrant detention through Agamben's logic of the camp across the social sciences. A 2006 theme issue of the journal Geografiska Annaler traces the genealogies of Agamben's ideas and outlines the importance of the biopolitical paradigm for contemporary humanities, social sciences, and political thought by providing analysis of particular spaces of detention as a state of exception (Gregory 2006), addressing aspects of the Northern European welfare system as a set of biopolitical measures (Landzelius 2006), and outlining the contradictory nature of contemporary identity formation by applying Agamben's framework to psychoanalytic theory (Papastergiadis 2006). In a vast discussion of empirical manifestations of Agamben's “camp,” Bülent Diken and Carsten Bagge Laustsen examine refugee camps, rape camps, gated communities, party tourism, and celebrity cultures in their book "The Culture of Exception: Sociology Facing the Camp" (Bülent Diken and Laustsen 2005). Extending the application of Agamben's camp to yet another group of "others," Kalpana Rahita Seshadri examines Internally Displaced Persions (IDPs) through a biopolitical framework in her article "When Home Is a Camp: Global Sovereignty, Biopolitics, and Internally Displaced Persons" (Seshadri 2008), emphasizing the biopolitical nature of global sovereignty. According to Seshadri, global sovereignty produces human displacement through depoliticization, making displaced persons into passive recipients of humanitarian aid under "global protection" (2008, 32).

Agamben's Homo Sacer has served not only as the basis for empirical investigations, but also as the basis for further theorizing of sovereignty, power, and thresholds. In the 2010 volume "The Deportation Regime: Sovereignty, Space, and the Freedom of Movement" 
(Genova and Peutz 2010), De Genova draws on Agamben's idea of the "threshold" as a space "at which, or across which, the regulation of human mobility (the thereby the subordination of labor) supply some of the crucial foundations of state power" (De Genova 2010, 50). To De Genova, spatial practices at a state's threshold are "intrinsically formative practices of citizenship itself” (2010, 51). In a similar fashion, Diana Martin (Martin 2015) takes the idea of Agamben's “threshold” as a starting point and develops a spatial model in which a camp meets the city, and a "campspace" is formed. The "campspace" is as a space where the refugee, the citizen and "other outcasts" meet (Martin 2015, 9). Claudio Minca (Minca 2015) also argues in favor of viewing a camp as a constitutive hub of broader political and geographic forms.

Some of Agamben's key points have also come under criticism from scholars of displacement. Naomi Millner criticized the Agambenian reading of detention sites for overlooking authority relations at the sites (Millner 2013). In a convincing critique of the homogenous image of "bare life" presented by Agamben, Hosna Shewly argues for examining the "vast array of processes that construct bare life" (Shewly 2013, 29). Similarly, in his article on mobility and deportation, Ethan Blue (2015) highlights the need of an expanded theorization of detention spaces as disjointed and multifaceted (Blue 2015, 14). Using Victor Turner's concept of liminality (1987) as a starting point, Blue claims that scholars of displacement should look at the "spatio-legal, even purgatorial, limbo between states and nations" as a variegated set of zones which "shift and contort, fold and distend, depending on the particular configurations of space, time and mobility" (Blue 2015, 3). My study builds upon Shewly's and Blue's calls for an expanded theorization of detention spaces as manifold rather than singular, focusing on classifications of migrants within a detention space. Here, a biopolitical reading of a detention space will be used as a tool for identifying nonmembers and gauging the discursive contours of the nation-state. 


\section{Empirical study: research design}

Border transit camp Friedland is located geographically in the very "middle" of Germany near the city of Goettingen. The camp was originally set up by British allied forces in 1945 to accommodate German expellees and prisoners of war returning from Eastern Europe in a cow barn. Situated on a major railway route, the camp was on the border between the America, British and Soviet occupation zones. Today, camp Friedland hosts up to 650 displaced persons from 11 countries at one time. It has a medical center, a Catholic church, a Protestant church, a day care center, a youth center, a large cafeteria, rooms for the migrants, a museum, as well as offices of the Federal Office of Administration (Bundesverwaltungsamt), which deals with co-ethnic migrants, and the Federal Office for Migration and Refugees.

There are several ways to arrive at Friedland today: undocumented migrants are sent here if they are caught by police; undocumented migrants come here to apply for asylum themselves (often after trekking though Greece or Italy); undocumented migrants are brought here by smugglers to apply for asylum; migrants whose residence permits have run out come here or are brought here by police to sort out their status; "quota refugees" from ongoing conflict areas (such as Syria) arrive here by plane for temporary settlement in Germany; coethnic migrants arrive here after applying and receiving invitations for resettlement from the German state. This is the only remaining camp that receives co-ethnic migrants today. Incoming migrants can either receive a temporary or permanent place of settlement somewhere in Germany, or be deported. People stay here typically for several months to 18 months; co-ethnic migrants today do not usually stay longer than two weeks.

This study is based on fieldwork conducted in January-March 2014, which included 10 hours of participant observation at border transit camp Friedland, four narrative interviews with co-ethnic repatriate families living at the camp, two interviews with asylum seekers 
living at the camp, two interviews with employees of the camp, two interviews with residents of the town where the camp is situated, and a two-hour official tour of the camp. The official tour was administered by a camp employee (a civil servant) whose job it is to give tours of the camp in addition to his regular bureaucratic duties at one of the camp's registration offices. The tour guide explained that tours are usually given on demand to organized groups of school children or university students, organized groups of people from retirement communities, or war veteran groups who come to the camp to learn about its history. The study also includes a visual discourse analysis of four monuments at the camp, and a critical discourse analysis of texts relating to the camp (the camp's website, notices distributed at the camp, newspapers and magazines distributed at the camp). Additionally, the materials gathered at the camp were supplemented with ten biographical interviews conducted with repatriates (co-ethnic migrants) who passed through the camp as they repatriated to Germany ${ }^{1}$.

Participant observation was conducted at the camp not only with the aim of producing field notes for analysis, but also with the aim of gathering visual and textual materials for subsequent discourse analysis. In this study, I have followed the framework of critical discourse analysis developed by Siegfried Jäger (2012), whose work is based on theories developed by Michel Foucault. Siegfried Jäger's work is in dialog with similar methodological frameworks developed by Ruth Wodak (1989) and Normal Fairclough (2006). The critical discourse analysis method employed here is cyclical in form: first a general characterization of all data is written out, then a corpus of textual documents is formed which is structurally analyzed according to basic textual characteristics. Then the data is coded in several rounds. In my third round of focused coding I determined the emerging

\footnotetext{
${ }^{1}$ Biographical interviews were conducted with co-ethnic migrants from all across Germany, selected through theoretical sampling (based on place of residence in Germany, country of origin, education level and level of engagement in politics).
} 
categories that then drove my selection of typical discourse fragments, which I analyzed according to a list of questions also formulated by Siegfried Jaeger. Thus, the following steps were taken in the critical discourse analysis of texts relating to the camp:

(1) General characterization of all data (list of sources and their importance)

(2) Structural analysis of data selected for the corpus (Jäger 2012)

(a) first round of word-by-word coding (Charmaz 2006)

(b) second round of line-by-line coding for contextualization

(c) third round of focused coding - emerging categories determined selection of typical discourse fragments for further analysis

(3) Detailed critical discourse analysis of typical discourse fragments (Jäger 2012)

The phase of structural analysis includes expanding upon the list of sources by noting structural elements of each source: date, type of text, format, authors, titles, sub-headings, font and design, visual elements such as graphs and pictures, a summary of the text, important quotes, sources of knowledge in the text (political science, medicine, media, etc.), collective symbolism, normative message, unique elements, political position, first impressions from the text. After such a description of each text, "typical fragments" which characterize other texts in the sample can be found. These typical fragments are then analyzed in the following manner (Jäger and Maier 2009, 55):

\section{(4) Context}

(a) Why was the article selected?

(b) Who is the author? What is her position and status?

(c) What are special areas of coverage of the author?

(d) What was the occasion of the article?

(e) In what section of the newspaper does it appear? 
(5) Surface of the text

(a) What is the layout like? Pictures and graphs?

(b) What are the headings and subheadings?

(c) How is the article structured into units of meaning?

(d) What topics are touched upon? (So what discourse strands is this a fragment of?)

(e) How do these topics relate to each other and overlap (entanglements of discourse strands?)

(6) Rhetorical means

(a) What kind and form of argumentation does the article follow? What argumentation strategy is used?

(b) What logic underlies the composition of the article?

(c) What implications and allusions does the article contrain?

(d) What collective symbolism is used (pictures, caricatures, statistics)?

(e) Idioms, sayings, clichés?

(f) Vocabulary and style?

(g) What actors are mentioned and how are they portrayed?

(h) What references are made (eg to science or sources)?

(7) Content and ideological statements

(a) What concept of humankind does the article convey?

(b) What concept of society does it presuppose?

(c) What concept of technology?

(d) What perspective regarding the future?

(8) Other peculiarities

(9) Discourse position and overall message. 
This method allowed me to conduct a thorough analysis of texts and images produced at the camp and about the camp by the state's agents (employees, politicians, officers, political parties). A critical discursive look at the texts and images through the lens of a biopolitical framework allowed me to come to several conclusions about the discursive contours of the German state. The results of my analysis are outlined below in a thematic discussion of the camp.

\section{Empirical study: analysis}

The discourses found at the transit camp include themes of victimization of ethnic Germans in the USSR, a discursive link of ethnic Germans from the USSR to the experience of German prisoners of war in the USSR, the idea of a "return home" for all ethnic Germans, and the discursive juxtaposition of an unfree East with a free, democratic West. These themes are analyzed below.

\section{The camp as part of an East-West border}

On the camp's website and during the official tour, the camp is presented as a "door" between East and West, unfreedom and freedom, and this metaphor holds constant both in relation to the times of the Cold War and in relation to the situation today.

In the post-war period and during the division of Germany, the camp stood on the border between all four occupational zones. This was the border between East and West Germany, and in a larger sense between the Eastern bloc and the West. Pointing to a large map hanging on the wall of the camp's museum labeled as "North Asia - political" (featuring contemporary Russia and the post-Soviet republics as well as Central and Eastern Europe, with dots denoting major settlement areas of ethnic Germans), the tour guide explained, 
"Almost no flows go east. Compared to the west, very few people go there." This statement was devoid of historical references and seemed to refer to a general pattern regardless of historical context. Speaking of ethnic German repatriates (also referred to as "RussianGermans") from the former Soviet Union and continuing to point at the map, the tour guide went on to explain the present-day situation: "Now, the Russian-Germans come mostly from Kazakhstan and Siberia, and other people come here mostly from Syria, Afghanistan, and Iraq." The swift transition of the tour narrative from migrations from former Soviet territories to migrations from "Syria, Afghanistan, and Iraq" depicts an ever-present East-West divide, in which the construction of "the East" includes Eastern Europe and the former USSR in one historical context, and "Syria, Afghanistan, and Iraq" in a more recent context. Thus, lines of demarcation between "East" and "West" are discursively redrawn by the tour guide depending on the group of refugees or migrants he was referring to, and regardless of its geographical or political reference point, "the East" was consistently described by the tour guide as the source of migrant or refugee "flows" to "the West."

During the tour, the guide also alluded to East-West borders within the EU by stating that "migrants leave their countries to escape conflict, arrive to Italy or Greece, but it's not far enough West for them, they want to come here [to Germany]." Here, we see that the EastWest rhetoric is used with regard to EU countries through which asylum seekers pass, with Germany depicted as the most "Western" destination for people fleeing poverty, war, and unfreedom. The depiction of Italy and Greece as transit states points to a hierarchy of borders depicted in the tour: the logic of the guide's speech at the camp reveals a construction within which migrants want to come to Europe, but do not want to stay in Italy or Greece, preferring Germany as their final destination. In this construction, we see a multi-step legitimation of Germany as a beacon of freedom and as a destination: Germany is positioned by the guide in a hierarchy above the East and communism, above developing states as sites of conflict from 
which people flee, and above other countries (Italy and Greece) within Europe. Thus, the camp retains its symbolic place between East and West across historical epochs.

\section{The camp as a transit space}

The camp is situated on a major transit route, on one of Germany's busiest railway tracks. This has practical and symbolic significance. Practically, as transportation officials are required to check documents, they can send undocumented migrants to camp Friedland from any railway connection. Additionally, undocumented migrants who wish to file for asylum or repatriates from are arriving from abroad can easily get to the camp using public transportation. Figure 1 shows the railway station Friedland, where asylum seekers and repatriates get off the train to come to the camp.

Figure 1. Friedland railway station, situated on one of Germany's busiest railway tracks. Photograph by Olga Zeveleva, February 2014.

On a symbolic level, the asylum seeker is rendered both mobile and immobilized at a camp and on a railway track. While for individuals who travel with visas and residence permits distances have shrunk in the age of globalization, asylum seekers are immobilized by bureaucratic barriers even if they are mobile enough to cross several borders on foot or in an undocumented fashion. This bureaucracy results in a situation where though asylum seekers are mobile and constantly on the move, they are also immobilized by state policies of recognition and documentation.

\section{The camp as the first place of arrival}

The tour of the camp and the internet resources related to it have pointed to the idea that 
borders change, yet the camp remains the "first place to go" for migrants. In all relevant text, the camp is continuously called "the first place of arrival" for asylum seekers, refugees and Russian-Germans. On one of the internet pages of the camp we see this word three times within two paragraphs ${ }^{2}$.

In fact, this camp is only a bureaucratic "first place of arrival," since physically migrants often arrive at an airport, go through border patrol, or arrive by boat to Italy or Greece, make a strenuous trip on foot through Italy and Greece. Others, such as one of the Russian-German families interviewed in the camp, go to their families' homes for the first night of their stay in Germany before proceeding to the camp to file their documents. Thus the camp is the first place where migrants get registered as legal subjects; in this way we see that the discourse of the "first place of arrival" hints at the fact that a person is devoid of subjectivity until she or he has undergone registration in the German state bureaucracy. Without papers one is not "in" Germany, rendering the migrant a subject merely insofar as the papers confirm her or his identity and right to be in Germany.

\section{A non-urban space}

Camp Friedland, like most other camps in Europe, is located in a rural area, a demonstratively peripheral site. Asylum seekers usually cannot afford transportation to major cities from this location. The space allocated for the camp is cheap land, and the camp itself is not integrated into any city with the aim of avoiding the formation of urban ghettos. The people at the camp are thus not integrated into any form of public life or urban life in Germany. This is a deliberately anti-urban structure, depicting a sterile image of order; to capture this kind of spatial organization, Richard Sennnett has used the metaphor "urban

\footnotetext{
${ }^{2}$ Landesaufnahmebehörde Niedersachsen - Standort Genzdurchgangslager Friedland http://www.grenzdurchgangslagerfriedland.niedersachsen.de/portal/live.php?navigation $\mathrm{id}=12831 \&$ psmand $=47$
} 
condom" to describe the camp.

The "urban condom" metaphor underscores the lack of integration of asylum seekers, refugees and repatriates at the camp into either the public life or the economic life in Germany. The people at the camp receive pocket money from the state (about 10 euros a week). In this situation, they have no means of acquiring economic capital, as they are outside the market economy. They are also supported with donations from the Red Cross, i.e. through "humanitarian aid." This aid is positioned outside of politics and is another element of the state's treatment of those who live at the camp as "bare life."

The official tour guide of the camp emphasizes the fact that the structure around the perimeter of the camp "is not a fence," and the buildings where people at the camp live "are not barracks." As the tour neared the perimeter of the camp and we stood near fence-like or barrack-like structures (see Figure 2), the guide explained, "people here are free to come and go as they wish. We don't have barracks here, and these [pointing at uniform one-story long buildings] are not barracks. These are not fences [pointing at a low metal barrier with a gate], they are there so that children do not run out into the street. We are careful not to build fences here." These points were mentioned several times by the guide, who also stressed that people living at the camp are intergrated into the greater town. The town itself, however, is home to very few businesses (in 2014, there was one supermarket, one hotel, one guest house, and one cafeteria) and few institutions that are not somehow related to the camp; according to both a local cafeteria owner and employes of Friedland, many of the town's residents even work at the camp.

Figure 2. Buildings at camp Friedland. Photograph by Olga Zeveleva, February 2014. 
The emphasis on the "non-fence" demonstrates an acute awareness of the connotations of a "camp" and stresses that people who stay there are actually free to leave and to be mobile. In reality, however, is that if they do leave, they will have no access to resources, to a livelihood, to services or housing, and if they are checked by authorities at any stage they will be sent back to this camp for evaluation and for bureaucratic procedures of identification and registration. The rhetoric of "this is not a fence" allows employees of the camp to claim that all the asylum seekers are there of their own free will; employees of the camp work in a bureaucratic structure that only allows them to see refugees as bare life, not as political subjects in need of a livelihood and of representation. Paradoxically, while the website of the camp and the offices located at the camp depict it as a "border" for incoming migrants, the tour guide depicts it as integrated into some kind of German space in the village, rendering the camp simultaneously inside and outside the state order.

In this way, bureaucratic barriers have replaced prison cells in the German case. The non-fence here is also a manifestation of the place of the refugee in German society: the refugee or asylum seeker is both external and internal to the society; his or her status is one of fundamental undecidabilty. The camp is where it is decided if the asylum seeker has the right to claim protection, or if she or he is in fact a threat to order who "illegally" crossed borders and tried to gain access to the European welfare system. If the latter becomes the verdict for a particular individual, the "illegality" of the border-crossing act is not an offense governed by a national criminal code, but rather it is governed by what Agamben claims is the "state of exception and martial law" (Agamben 1998, 95). This peculiar situation renders the rejected asylum seeker a criminal beyond the criminal code, suspended in a state of illegality on the threshold of the nation-state. 


\section{A space for waiting}

The strategy of confining people in a camp not only aims to keep refugees from integrating into local contexts, labor markets, schools, but it keeps them in a position of waiting for an indefinite period of time until it is decided whether they can stay in Germany. This position of waiting is part of the physical structure of the camp: temporary ID cards are given to each new arrival, and the ID cards have a page for meal stamps attached. There are seven meals on a given card, and once a person receives a meal their card is stamped next to the date. Since no one knows how long they will be at the camp, the asylum seeker receives a new card at the beginning of each new week, which is stapled atop the old one. An asylum seeker from Eritrea showed me over a dozen pages of the food stamps stapled on top of one another; she had been at Friedland for three months and it was unclear how much longer she would stay. "I remember how long I am here by the stamps," the asylum seeker from Eritrea explained to me, flipping through the pages attached to her ID card. "A group of 13 of us came here, crossing Italy. The rest have gone [away from the camp], we will maybe go soon too, to somewhere in Germany," she told me during our interview, pointing to herself and another woman from Eritrea.

This merging of an identity card which is suitable only inside the camp and which is attached to meal stamps issued weekly is a physical reminder that the asylum seeker has been reduced to "bare life" - the woman is not a political or social being, but a biological entity whose identity exists only within the camp, while the camp provides her with only food and shelter. Her use of the food stamp pages as a sort of calendar reveals the connection she has made between satisfying her basic needs and telling time, a process governed by the rhythms of the camp's schedule. To her, the food stamps are a way of keeping track of exactly how long she has waited for a decision on her status, and time itself becomes equivalent to 
waiting. The function of the camp as a space for waiting is further underscored by the numerous waiting rooms inside each official building located there, and the camp becomes a space in which regular time governed by the rhythms of social life is suspended.

\section{The construction of the passive migrant}

In the tour of the camp and on the official website of the camp, the migrants always "are invited," "are registered," "are medically examined," "are given pocket money." Even with regard to the trip that some asylum seekers take, they "are brought by smuggling gangs" in the narrative of the tour guide of Friedland. In this vein, the words "wave" or "inflow" are often used in texts relating to the camp: "inflow of migrants," "migrant wave."

We see this theme manifested physically in the sculptures placed in Friedland. One of the sculptures (see Figure 3), situated right outside the cafeteria of the camp, shows a symbol of rugged and uninviting East in the shape of one water basin, out of which water flows along a long bronze path westward, into another water basin symbolizing the West (this interpretation was offered by the camp's tour guide, who cited the sculptor's line of thinking). From this we can conclude that the water depicts the passive flow of people from "East" to "West." In addition to this visual manifestation of the East-West dichotomy discussed above, this symbolism further underscores the image of the passive and anonymous "mass" of people coming to the camp.

Figure 3. Sculpture situated outside the cafeteria of camp Friedland. Photograph by Olga Zeveleva, February 2014.

The sculpture is placed centrally, standing right in front of the entrance to the cafeteria and near the main gate leading into the camp from the Friedland train station. Moreover, the 
sculpture is designed to look like it is a natural part of the camp's landscape, growing straight out of the cobblestones and lined with the same cobblestones as those that people walk on. This implies that the scuplture articulates the same spatial and symbolic meanings that the camp stands for.

\section{Classifications of migrants at the camp}

There are several ways of ending up at this camp today. The tour guide at the camp outlined the following pathways:

(1) Quota refugees are picked out by the UNHCR and the German government;

(2) Smugglers may bring undocumented migrants to the camp;

(3) The legal status of migrants who have resided in Germany may expire and they come to the camp to renew their status;

(4) A person can come to the camp themselves, without smugglers and without documents;

(5) The police may send undocumented migrants to the camp;

(6) Jewish repatriates can claim residency and citizenship in Germany in accordance with post-World-War-II laws;

(7) Co-ethnic migrants of German descent from former Soviet states can immigrate and claim German citizenship, for which co-ethnics apply before their departure to Germany.

According to my interview with a civil servant working at one of the registration offices of the camp, quota refugees (from category 1 in the list above) mostly include those fleeing from Syria (the interview was conducted in February 2014). Syrians wishing to be granted a place in Germany's resettlement program must first register with the International 
Organization for Migration in Beirut. They are subsequently vetted by the German government and the UNHCR according to three criteria. In the interview, the camp employee outlined three criteria for picking out refugees for the quota:

(1) The first includes those needing to leave Syria for humanitarian reasons, such as people who are disabled or require special medical attention that is not available in Syria. Women and children are considered for this category first.

(2) The second group includes those with some sort of affiliation to Germany: Either they have attended a school or university in Germany in the past, or they have family members already living in the country. A basic knowledge of the German language also counts in the applicant's favor.

(3) The third group of refugees, meanwhile, are chosen according to their ability to rebuild Syria once the civil war is over. This group includes doctors, engineers, intellectuals, and academics.

The hierarchy of "most desired" asylum seekers who are included in refugee quotas is based firstly on the German state's recognition of severe conflict (Syria is recognized as a place of particular hardship), thus transferring the issue of humanitarian aid to an issue of human rights and the right to relocation, especially pertinent in the case of the disabled and the young; secondly, those refugees who can be included in the quota who already have ties to Germany or who are particularly "valuable" members of society are also given priority over others.

The symbolic space of the camp, i.e. most sculptures and the museum, reflects only the background and history of the co-ethnic migrants, but silences the narratives of all the other groups mentioned in the list above. The camp has no synagogues or mosques, but there are three churches around the camp and in the camp. The museification of the camp includes 
a depiction through maps and photographs of Germany World War II POWs returning from the Soviet Union to Germany in the 1950s. The sculptures at the camp are also dedicated to the POW history. The museum of the camp, located currently in a museified barrack from the 1950s (see Figure 4), shows maps of the Soviet Union where the POWs and the co-ethnic migrants came from before resettling to their "home" in West Germany. Thus, these symbols depict that camp as a place of arrival for Germans; non-ethnic-German incoming migrants are not included in the symbolic narrative of the camp.

Figure 4. Camp Friedland museum. The building is a model of one of the camp's living quarters barracks from the 1950s. Photograph by Olga Zeveleva, February 2014.

\section{A discourse analysis of co-ethnic migrants at the camp}

At camp Friedland on shelves in the waiting rooms there was ample reading material placed especially for the co-ethnic migrant audience. The literature included the magazine of the "Germans from Russia” Association, a publication called "A People on the Road." As there were many copies of this publication at the camp, making it the most prominent and most often renewed reading material (the camp has a subscription and new issues are delivered there), I have conducted an additional analysis of the magazine dating to the month during which I conducted my fieldwork.

The magazine is about Russian-Germans and is published for Russian-Germans (coethnic migrants). Its focus lies on people who have migrated to Germany as co-ethnic repatriates. During fieldwork at the camp, issues from January and February 2014, as well as one issue from December 1995, were found in the waiting areas. 
My analysis of the magazines has shown that there are three types of stories typically presented on its pages: success stories; volunteer stories of Russian-Germans helping with integration projects; family histories with a focus on stories of repression in the USSR.

The January 2014 issue featured images that were exclusively portraits of RussianGermans, save one image - a sculpture by a Russian-German sculptor of a woman in the Trudarmee, or Soviet hard labor camp. This issue features two stories about Mennonites; the stories focus on the Mennonites' lamentation of the fact that despite their native German language, they are still perceived as "immigrants" from Russia in Germany. Thus, the magazine exhibits a clear focus on ethnicity, integration, success of integration, and the experience of repressions of ethnic Germans in the USSR as a defining feature of their migration experiences and their choice to come to Germany. The following excerpt is a typical discourse fragment from the magazine A People on the Road:

\footnotetext{
“Robert Huber's favorite hobby is studying his family tree. [...] With Ludwig Huber's migration 250 years ago a family history began. This is a history many [German] colonists share. Robert Huber, an eighth generation descendant, brought his family back to Germany. This is ten Huber generations.

"It has come full circle. I came back to the place where my family history began with Catherine's [Catherine II of Russia] invitation," said Robert Huber during an interview at an event held by the Hamburg chapter of the Compatriot Organization [of Germans from Russia] and the Hamburg Association of Germans from Russia at the Ethnographic Museum of Hamburg in November 2013. Thanks to Huber's efforts the Compatriot Organization of Germans from Russia enjoys a very good reputation in the state Schleswig-Holstein. The past five years have been especially eventful: many events were actively supported and held. [...]"

(Source: Magazine "Volk auf dem Weg" (“A People on the Move"), January 2014, page 37. By Nina Paulsen).
}

In this excerpt, we see the importance of a cyclical movement of an ethnic German coming back to the home his ancestors left centuries ago. We also see a clear generalization 
of Rober Huber's family history to "a history many... share." Embedded in this story is also its significance for the activities of the Compatriot Organization of Germans from Russia (an organization based in Germany). Thus, in this short text, we are presented with a collective history, an ethnic-German-centric conception of identity, the importance of the individual story for the activities and funding of the group, and the depiction of Germany as "home" for the Russian-German co-ethnic migrants.

The tour of the camp, the camp's website, the placement of the magazines, and other symbolic elements of the camp all emphasize the idea of "ethnic Germans" coming home. This solidifies the notion of an ethnic German nation-state as a destination for all ethnic Germans. In this way, the camp is a symbolic place of freedom for Germans.

In this context, the Russian-German co-ethnic migrants occupy a peculiar place: they comprise a category of persons admitted to camp Friedland alongside two other categories, those of refugees and asylum seekers. But upon further analysis, we see that in narratives of the camp the Russian-Germans actually occupy a symbolic place next to the prisoner of war returnees from the 1950s. This is the narrative that has been museified in the exhibition dedicated to the camp.

Thus, although the camp has taken on new functions as a place of temporary residence for asylum seekers and refugees, it is the story of the ethnic Germans that comes to the forefront, is museified and depicted on photographs, is depicted in sculptures at the camp, and is presented in the reading material provided in waiting rooms.

\section{Conclusions}

This study shows how camp Friedland discursively builds up a narrative for some migrants, while silencing the narratives of others. While German POWs (as repatriates from the 1950s) 
and co-ethnic German migrants from former Soviet states (as modern-day co-ethnic repatriates) are granted symbolic presence through sculptures and in the museum at the camp, all other kinds of migrants (refugees and asylum seekers, as well Jewish migrants, who comprise a group of non-ethnic German repatriates) have no discursive presence in the symbolic spaces of the camp. The spatial articulations of inclusion are governed by very specific national identity narratives of the German state. These narratives include a focus on ethnicity and blood, on repressions in an unfree East, and on Germany as a home to all Germans.

Thus we see the camp as a space of classification and hierarchization both of people and of narratives; the state produces and reproduces these narratives in order to create the discursive boundaries of its membership, and also to create a hierarchy of nonmembers. While co-ethnic migrants arrive as nonmembers, the high likelihood that they will receive first residency status and then citizenship status means they are accepted into the structures of the nation-state and recognized as members. This readiness of recognition by the state is discursively manifested in the symbolic spaces of the camp. The co-ethnic migrants become part of the state's political life.

Other nonmembers of the state are divided into the larger categories of quota refugees and other asylum seekers. Quota refugees are those who have not suffered at the hands of an internationally denounced regime or group (e.g. in Syria today), are those who are defined by the state and the UNHCR as needing particular humanitarian attention, and also those who are educated or who already have ties to Germany. Those who do not make the quota are turned away; they are not invited to Germany in the first place.

Yet another group of even further removed nonmembers are those who are not included in any quota, such as this study's interviewees from Eritrea. While Syrians who escape Syria in an undocumented fashion and make their way to Germany have a high chance 
of receiving asylum, undocumented migrants from other states end up spending much longer periods in spaces of detention with an even more uncertain outcome. Those who are deported are the ultimate "nonmembers." All who have passed through the camp who have not gone on to receive residency in Germany have been abandoned by the sovereign; both individually and as an abandoned collective, they define what Germany is not and never will be. Their lives will also be marked by the experiences of detention and deportation, thus they will be linked to the sovereign power of the German state through being abandoned by the German state.

With that, the camp is the ultimate spatial manifestation of sovereign power, a space "outside" the state but subject to the state's power through abandonment. At the camp, state agents construct national identity through defining political life and by classifying various types of "bare life," some of which can move up in the hierarchy and gain greater degrees of recognition, while others remain stripped of political subjectivity and face deportation. Ultimately, the state's depoliticized subjects remain tied to it by virtue of being defined by the sovereign as nonmembers. It is by focusing on the nation-state's nonmembers and the spaces they occupy at the border that we are able to gain a better understanding of the multifaceted, hierarchical nature of national identity and the violent nature of its thresholds. Moreover, the focus on non-membership hierarchies proposed here allows us to lay the foundations for imagining new loci for both identity-formation and political action which lie beyond the nation-state, while at the same time being products of its demarcation. 


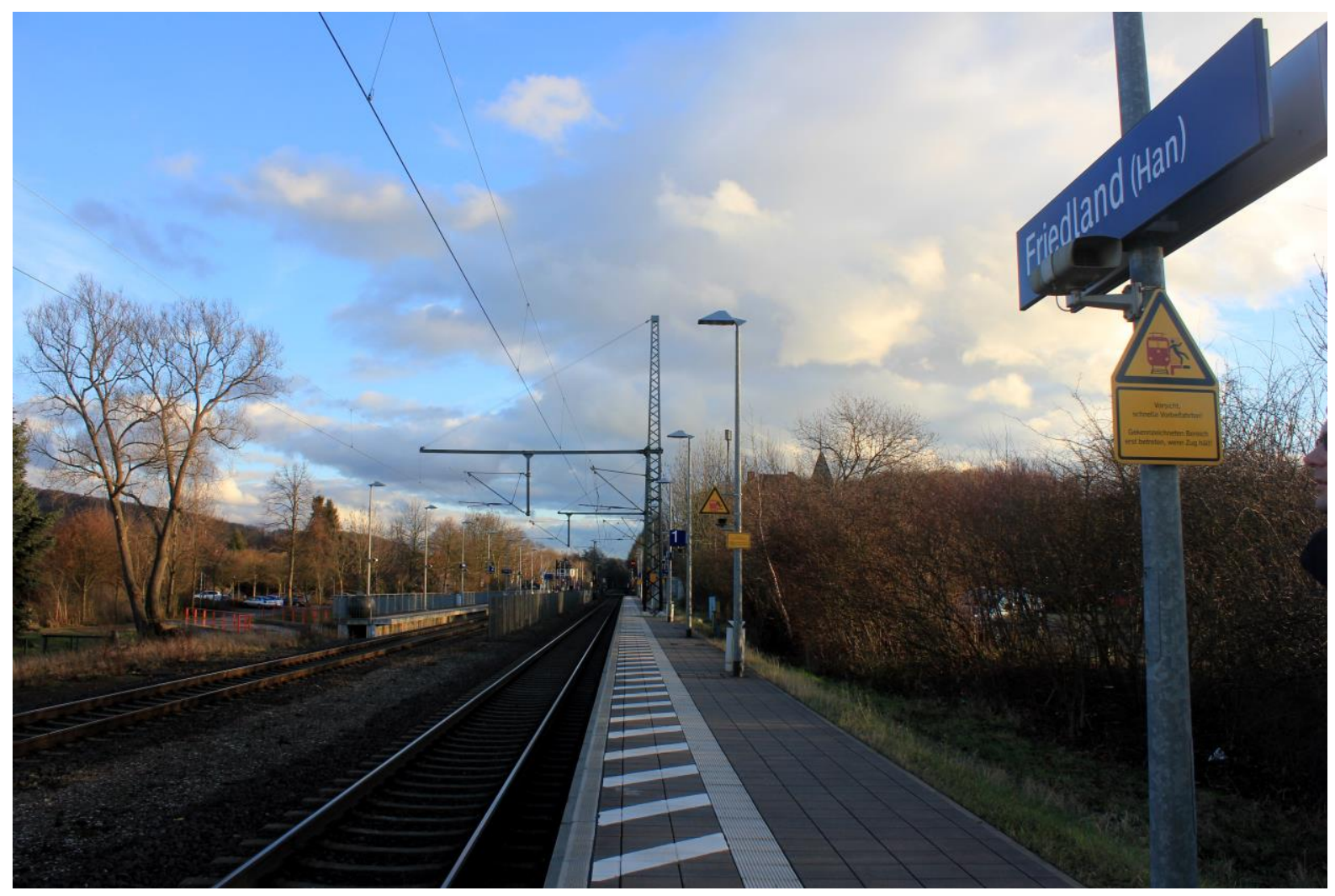

Figure 1

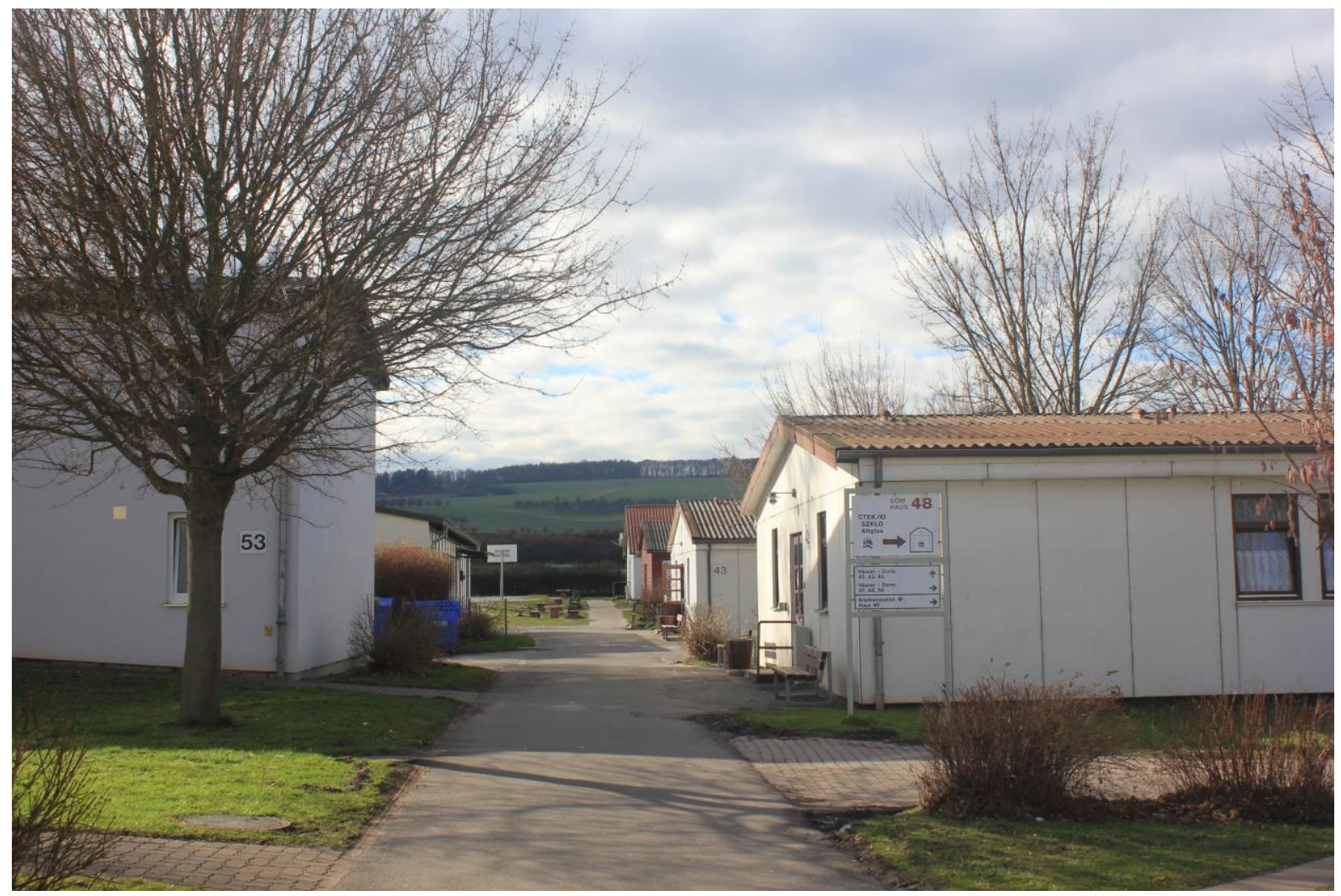

Figure 2 


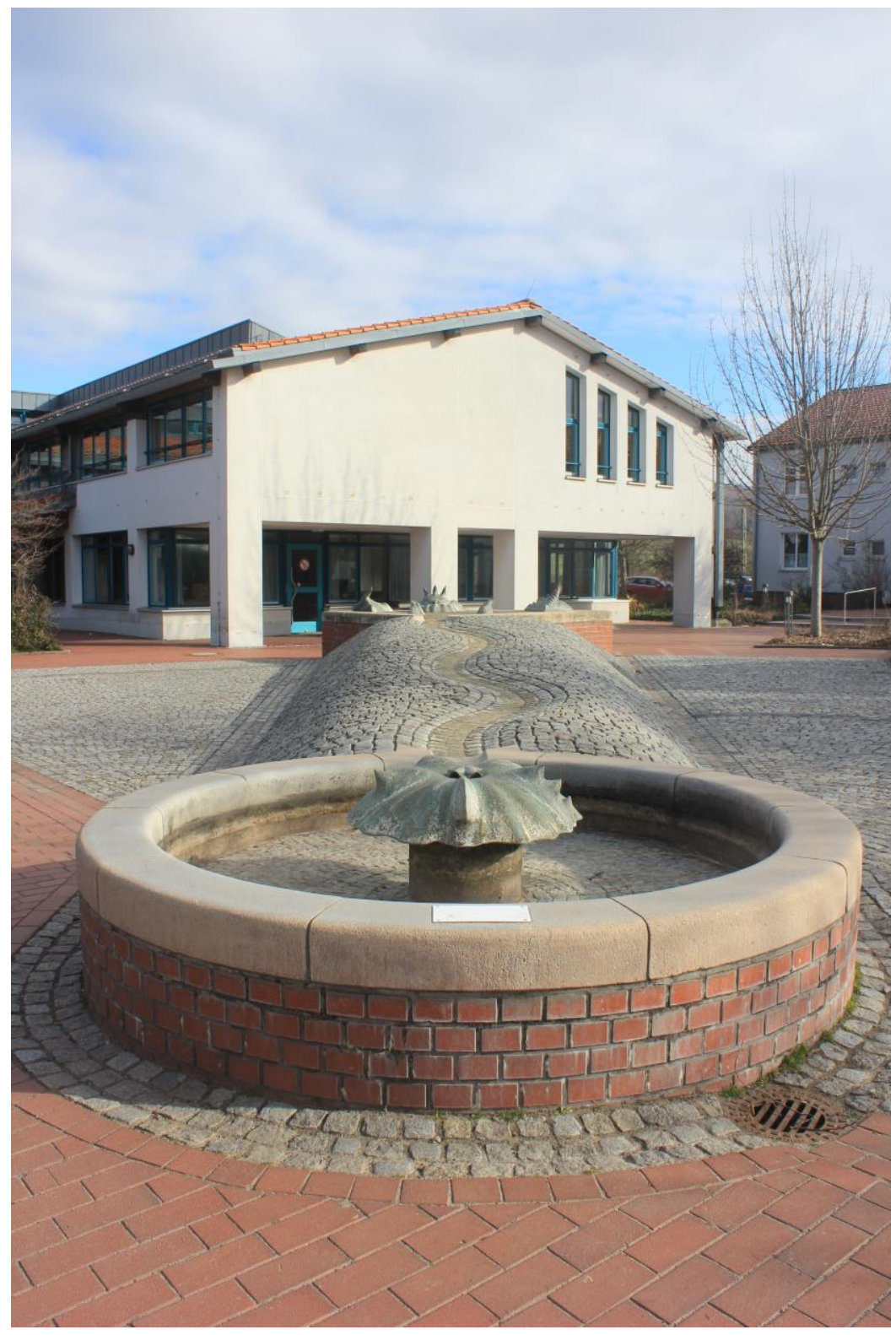

Figure 3 


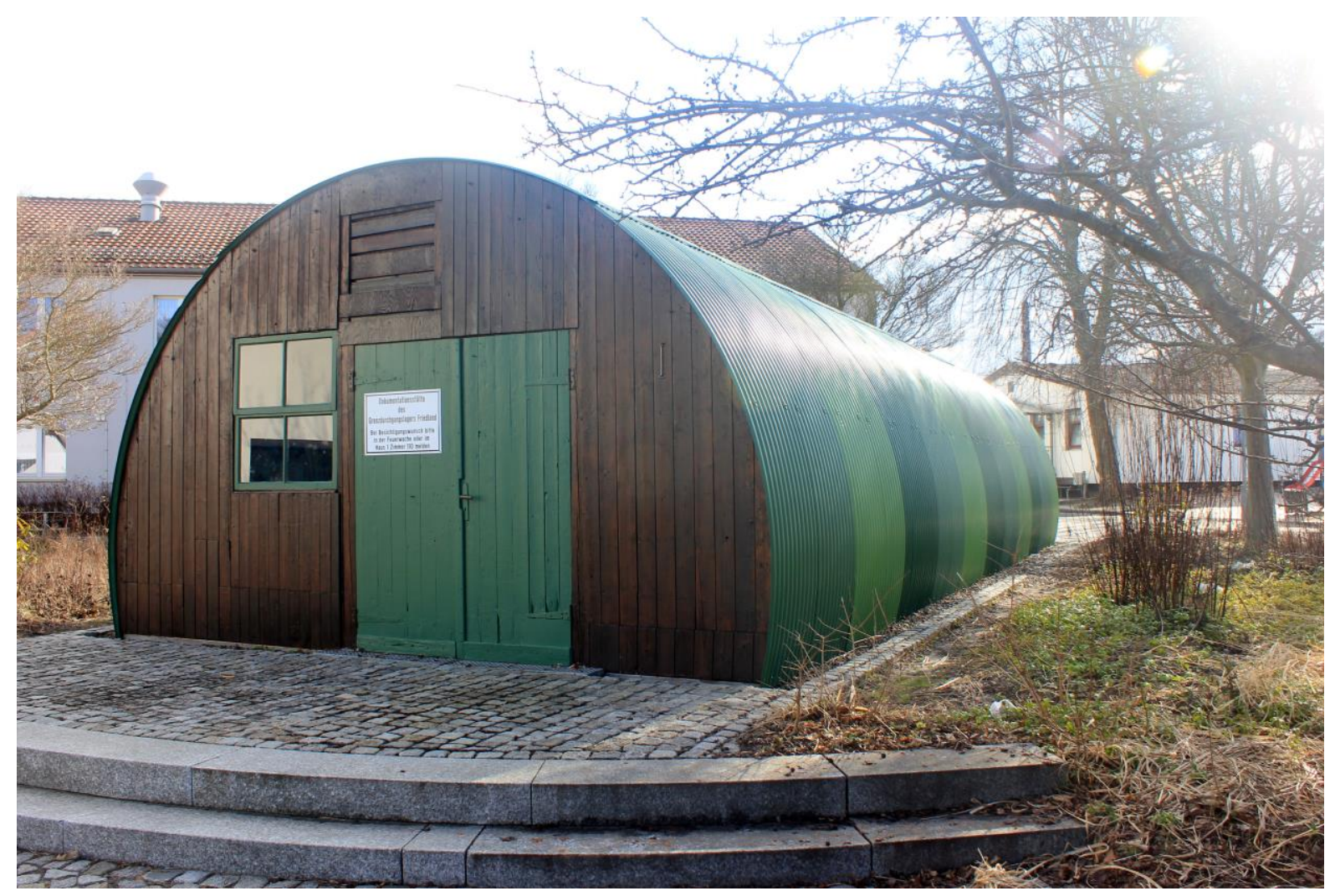

Figure 4

\section{Acknowledgements}

I thank Niklas Radenbach for his help and support during my fieldwork; Lena Inowlocki and Ursula Apitzsch for their helpful comments during the colloquium on biographical sociology at the Goethe University in Frankfurt; Sergei Medvedev and Andrey Makarychev for their stimulating Escapes from Modernity winter school in Estonia, where I presented my preliminary results. Thank you also to the anonymous reviewers for their excellent suggestions.

\section{References}

Agamben, Giorgio. 1998. Homo Sacer: Sovereign Power and Bare Life. Stanford University Press.

Agnew, John. 1994. "The Territorial Trap: The Geographical Assumptions of International Relations Theory." Review of International Political Economy 1 (1): 53-80.

Anderson, Benedict. 2006. Imagined Communities: Reflections on the Origin and Spread of Nationalism (revised edition). London: Verso.

Arendt, Hannah. 1958. The Origins of Totalitarianism. Meridian Books. 
Blue, Ethan. 2015. "Strange Passages: Carceral Mobility and the Liminal in the Catastrophic History of American Deportation.” National Identities 17 (2): 175-194. doi:10.1080/14608944.2015.1019208.

Brenner, Neil, and Stuart Elden. 2009. "Henri Lefebvre on State, Space, Territory." International Political Sociology 3 (4): 353-77. doi:10.1111/j.17495687.2009.00081.x.

Charmaz, Kathy. 2006. Constructing Grounded Theory: A Practical Guide through Qualitative Analysis. SAGE.

Diken, Bülent, and Carsten B. Laustsen. 2005. The Culture of Exception: Sociology Facing the Camp. 1 edition. Abingdon, Oxfordshire; New York: Routledge.

Diken, Bülent, and Carsten Bagge Laustsen. 2005. "The Ghost of Auschwitz.” Journal for Cultural Research 9 (1): 69-85. doi:10.1080/1479758042000331943.

—. 2006. "The Camp." Geografiska Annaler: Series B, Human Geography 88 (4): 44352. doi:10.1111/j.0435-3684.2006.00232.x.

Ek, Richard. 2006. "Giorgio Agamben and the Spatialities of the Camp: An Introduction." Geografiska Annaler: Series B, Human Geography 88 (4): 363-86. doi:10.1111/j.0435-3684.2006.00228.x.

Foucault, M. (1984, orig, 1967) 'Of Other Spaces: Utopias and Heterotopias', Architecture / Mouvement / Continuite trans. Jay Miskowiec, October 1984: 1-9

Genova, Nicholas De, and Nathalie Peutz. 2010. The Deportation Regime: Sovereignty, Space, and the Freedom of Movement. Duke University Press.

Gregory, Derek. 2006. “The Black Flag: Guantánamo Bay and the Space of Exception.” Geografiska Annaler: Series B, Human Geography 88 (4): 405-27. doi:10.1111/j.0435-3684.2006.00230.x.

Harvey, David. 1996. Justice, Nature and the Geography of Difference. 1 edition. Cambridge, Mass: Blackwell.

Herb, Guntram Henrik. 1999. Nested Identities: Nationalism, Territory, and Scale. Rowman \& Littlefield.

Horner, Jed, and John Rule. 2013. "The Politics of Space and the Spatialisation of Politics: New Directions for Examining the Connections between Immigration and Contagion." New Political Science 35 (3): 463-78. doi:10.1080/07393148.2013.813699.

Hussain, Nasser, and Melissa Ptacek. 2000. “Thresholds: Sovereignty and the Sacred.” Law \& Society Review 34 (2): 495. 
Kaplan, David H., and Guntram H. Herb. 2011. "How Geography Shapes National Identities.” National Identities 13 (4): 349-60. doi:10.1080/14608944.2011.629424.

Landzelius, Michael. 2006. “'Homo Sacer' out of Left Field: Communist 'slime' as Bare Life in 1930s and Second World War Sweden." Geografiska Annaler: Series B, Human Geography 88 (4): 453-75. doi:10.1111/j.0435-3684.2006.00233.x.

Lefebvre, Henri. 1991. The Production of Space. 1 edition. Malden, Mass.: Wiley-Blackwell. Lowenthal, David, Paul Claval, Marie-Claire Robic, Gerhard Sandner, Mechtild Rossler, Keiichi Takeuchi, Mark Bassin, David Hooson, Lisa E. Hussman, and Anne Buttimer. 1994. Geography and National Identity. Oxford England; Cambridge, Mass: Blackwell Publishers.

Martin, Diana. 2015. "From Spaces of Exception to 'campscapes': Palestinian Refugee Camps and Informal Settlements in Beirut.” Political Geography 44 (January): 9-18. doi:10.1016/j.polgeo.2014.08.001.

Millner, Naomi. 2013. "Routing the Camp: Experiential Authority in a Politics of Irregular Migration." Journal of Political Power 6 (1): 87-105. doi:10.1080/2158379X.2013.774978.

Minca, Claudio. 2015. “Geographies of the Camp.” Political Geography, January. doi:10.1016/j.polgeo.2014.12.005.

Papastergiadis, Nikos. 2006. "The Invasion Complex: The Abject Other and Spaces of Violence.” Geografiska Annaler: Series B, Human Geography 88 (4): 429-42. doi:10.1111/j.0435-3684.2006.00231.x.

Peters, Bernhard. 2002. "A New Look at How Should We Think about or? Are There Two Types of National Identities? Does Germany Have an Ethnic Identity, and Is It Different?” European Journal of Sociology / Archives Européennes de Sociologie 43 (1): 3-32. doi:10.1017/S0003975602001005.

Rembold, Elfie, and Peter Carrier. 2011. "Space and Identity: Constructions of National Identities in an Age of Globalisation." National Identities 13 (4): 361-77. doi:10.1080/14608944.2011.629425.

Schlögel, Karl. 2003. Im Raume lesen wir die Zeit: Über Zivilisationsgeschichte und Geopolitik. 3rd ed. München: Carl Hanser Verlag GmbH \& Co. KG.

Schmitt, Carl. 2003. The Nomos of the Earth in the International Law of the Jus Publicum Europaeum. Telos Press Publishing. 
Seshadri, Kalpana Rahita. 2008. "When Home Is a Camp Global Sovereignty, Biopolitics, and Internally Displaced Persons." Social Text 26 (1 94): 29-58. doi:10.1215/01642472-2007-018.

Shah, Nisha. 2012. "The Territorial Trap of the Territorial Trap: Global Transformation and the Problem of the State's Two Territories1." International Political Sociology 6 (1): 57-76. doi:10.1111/j.1749-5687.2011.00144.x.

Shewly, Hosna J. 2013. "Abandoned Spaces and Bare Life in the Enclaves of the IndiaBangladesh Border.” Political Geography 32 (January): 23-31. doi:10.1016/j.polgeo.2012.10.007.

Simmel, Georg, David Frisby, Mike Featherstone. 1997. Simmel on Culture: Selected Writings. London: Thousand Oaks, Calif.: Sage Publications.

Simmel, Georg. 1958. Soziologie: Untersuchungen Über die Formen Der Vergesellschaftung. Berlin: Dunckert und Humboldt.

Simmel, Georg and Kurt H. Wolff. 1950. The Sociology of Georg Simmel. Glencoe, IL: Free Press.

Warf, Barney, and Santa Arias, eds. 2008. The Spatial Turn: Interdisciplinary Perspectives. 1 edition. London; New York: Routledge.

Withers, Charles W. J. 2009. "Place and the' Spatial Turn' in Geography and in History." Journal of the History of Ideas 70 (4): 637-58. 